\section{Physical aptitude related to the health of initial graders: A study between groups assisted and non assisted by a Physical Education professional}

\author{
Aptidão física relacionada à saúde de \\ escolares das séries iniciais: um estudo \\ entre turmas assistidas e não assistidas pelo \\ profissional de Educação Física
}

Debora Tornquist ${ }^{1}$

Luciana Tornquist ${ }^{1}$

Cézane Priscila Reuter ${ }^{3}$

Miriam Beatris Reckziegel ${ }^{3}$

Leandro Tibiriça Burgos ${ }^{3}$

Miria Suzana Burgos ${ }^{2}$

\begin{abstract}
The aim of this study consists in checking possible differences in aptitude levels related to health, among students in the first school years, who participate in Physical Education lessons given by a qualified professional instructor (municipal and private schools) and students who attend lessons given by regular schoolmasters (state schools). The subjects of this study are 626 students of the initial school years, in the municipality of Santa Cruz do Sul (RD). Evaluations included Body Index Mass, Body Fat Percentage, Resilience, Abdominal Resistance and Cardiorespiratory Resistance. The results attest that the state schools, without the assistance of a professional Physical Education Teacher, presented a bigger percentage of unsatisfactory results in the evaluated variables, with the only exception of Abdominal Muscle Resistance. Differences between averages by school network were detected with regard to Resilience, with averages significantly lower in state schools, without a professional Physical Education instructor; and Cardiorespiratory Resistance, with state schools again showing significantly lower averages compared to other school networks. In general, in our study, it was possible to observe that students attending lessons given by professional Physical Education instructors presented better physical aptitude indices for resilience and cardiorespiratory resistance if compared to students whose lessons are given by regular schoolmasters.
\end{abstract}

\section{Keywords}

Physical aptitude; Children; Schoolmasters.

\section{Resumo}

Este estudo objetiva verificar possíveis diferenças nos niveis de aptidão física relacionados à saúde, entre escolares das séries iniciais, que participam de aulas de Educação Física ministradas por profissional habilitado (escolas municipais e particulares) e alunos em que as aulas são ministradas pelo professor unidocente (escolas estaduais). São sujeitos deste estudo 626 escolares dos anos inicias, do município de Santa Cruz do Sul (RS). Foram avaliados o Indice de Massa Corporal, Percentual de Gordura, Flexibilidade, Resistência Abdominal e Resistência Cardiorrespiratória. Os resultados demonstram que as escolas estaduais, sem a assistência do profissional de Educação Física, apresentaram maiores percentuais de resultados insatisfatórios nas valências avaliadas, com exceção apenas da Resistência Muscular Abdominal. Diferenças entre as médias por rede de ensino foram observadas para a Flexibilidade, com médias significativamente inferiores das escolas estaduais, sem o profissional de Educação Física; $e$ Resistência Cardiorrespiratória, também com a rede estadual apresentando médias significativamente inferiores às demais redes de ensino. Em geral, em nosso estudo, foi possível observar que os alunos com aulas ministradas pelo profissional de Educação Física apresentaram melhores indices de aptidão física para a flexibilidade e resistência cardiorrespiratória quando comparados aos escolares que possuem aulas com o professor unidocente.

\section{Palavras-chave}

Aptidão física; Crianças; Docentes.
Rev Bras Ativ Fis Saúde p. 298-308 DOI:

http://dx.doi.org/10.12820/rbafs.v.18n3p298

1 Educação Física. Universidade de Santa Cruz do Sul (UNISC)

2 Programa de Pós-Graduação em Promoção da Saúde. Universidade de Santa Cruz do Sul. Santa Cruz do Sul, RS

3 Universidade de Santa Cruz do Sul. Santa Cruz do Sul, RS. 


\section{INTRODUCTION}

Physical education (PE) is provided for in the elementary school curriculum in Brazil in accordance with Act no. 10,328 that amended Article $26 \S 3$ of the Education Act 9394/1996 noting that $\mathrm{PE}$ is an integrated part of school teaching approach and a compulsory education component. ${ }^{1} \mathrm{PE}$ is a mandatory requirement nationwide and states and municipalities are responsible for providing PE programs but the law does not clearly specify who should deliver these classes. ${ }^{2}$

The minimum qualifications under Article 62 of the Education Act 9394/1996 for teaching kindergarten and the first four grades of elementary school is complete teacher training. Thus, those with complete teaching training or even a degree in Education can work as a teacher and can provide instruction in all curriculum components of kindergarten and early grades including $\mathrm{PE}{ }^{3}$

In the southern state of Rio Grande do Sul, in accordance with Act $8747 / 88,{ }^{4}$ bonuses are granted to generalist teachers instructing children in the early grades in state schools. Thus, a single generalist teacher teaches all curriculum components in the early grades in state schools in Rio Grande do Sul. The teachers can have a degree in Education or can be certified in teacher training or even trained in a specific area. Because of these bonuses, they teach all subjects at these schools.

The same is seen in other Brazilian states. In some municipalities, schools do not have physical educators working with children in the early grades. A study conducted in the city of Várzea Grande, central-western state of Mato Grosso, showed that, of 63 municipal schools, only three had physical educators providing classes to children in the early grades as they had special PE programs in these schools. ${ }^{2}$ In the city of Santo André, southeastern state of São Paulo, of 44 public municipal schools, only 10 had qualified physical educators providing classes to children in the early grades. ${ }^{5}$ Although these teachers are considered legally qualified to teach $\mathrm{PE}$ to children in the early grades, several studies with generalist teachers have reported they feel unprepared and insecure to provide $\mathrm{PE}$ classes. ${ }^{5,6,7,8,9}$

Betti and Zuliani ${ }^{10}$ have argued that, as a component of the education curriculum, PE should promote physical culture among schoolchildren so that they will grow up to be citizens who are able to engage in dancing, games, sports, and physical fitness practices for enjoying a good quality of life. Marques and Gaya ${ }^{11}$ have underlined that school PE programs should help the improvement of physical fitness components. They have pointed out that, in addition to dance, games and sports, school programs should be aimed at improving physical fitness of schoolchildren to improve their general health.

This study aimed to assess potential differences in health-related physical fitness among schoolchildren in the early years participating in PE programs provided by qualified physical educators (public municipal and private schools) and those receiving instruction by generalist teachers (public state schools).

\section{METHODS}

This is a cross-sectional quantitative study based on data obtained from the Health and Lifestyle Habits in School and Family in Urban and Rural Areas of 
Santa Cruz do Sul Study that evaluated 1,578 students aged 7 to 17 years living in the city in 2007, 2008 and 2009. The study was approved by the Universidade de Santa Cruz do Sul Human Research Ethics Committee (CEP - UNISC, protocol number 4913/07).

The study population consisted of 20,540 elementary and middle and high school students from 69 both public and private schools in the city Santa Cruz do Sul: 11,679 were from public state schools; 6,813 from public municipal schools and 2,048 from private schools. The schools were stratified by rural and urban areas. Urban area schools were divided into central and peripheral areas (north, south, east and west). Data were collected from the 6th Regional Education Board and Department of Education of Santa Cruz do Sul, in 2007. The sample size was calculated using the National Education Association Research Division and Gil's formula (1999), as proposed by Christensen, ${ }^{12}$ with a $5 \%$ significance level. We calculated the number of schools and students from the entire population to participate in the study. We estimated a sample of around 400 participants to be representative of the city but we actually evaluated a larger sample of participants $(1,578)$ from 18 schools (6 municipal, 10 state and 2 private) in Santa Cruz do Sul.

After estimating the number of students and schools by area, students were randomly selected applying the following inclusion criteria: being 7 to 17 years of age; providing an informed consent form signed by their parents or guardians; and filling out the study questionnaire.

Since the purpose of the study was to evaluate schoolchildren in early grades we conducted a cross-section of the above described study sample and selected only those attending grades 1 to 4 . Thus, we evaluated 626 schoolchildren in the early grades, of which 333 were males and 293 females, with a mean age of 9.07 $( \pm 1.54)$ years.

Of all children participating in the study, 282 (127 females and 155 males) attended PE classes provided by qualified physical educators: 212 students from municipal schools (95 females and 117 males) with a mean age of $9.38( \pm 1.71)$ years and 70 from private schools (32 females and 38 males) with a mean of 8.51 $( \pm 1.23)$ years. In addition, 344 students from public schools (166 females and 178 males) with a mean age of $8.99( \pm 1.44)$ years attended classes provided by generalist teachers.

Evaluations were performed at each school on a different day within the school premises. Students were evaluated individually in a single day, except for the 9-minute run test that was performed collectively. Health indicators were assessed following the protocols described in the Projeto Esporte Brasil (PROESPBR) Manual ${ }^{13}$ : body mass index (BMI); flexibility (sit-and-reach test); abdominal muscle strength (sit-up test); and the nine-minute run test (cardiorespiratory endurance).

We calculated BMI by measuring weight and height of schoolchildren and applying the formula BMI = weight $(\mathrm{kg}) /$ height $(\mathrm{m})$. They were classified according to the PROESP-BR tables. ${ }^{9}$

We performed the sit-and-reach test to measure flexibility. Participants were positioned sitting on the floor with legs fully stretched out straight ahead, barefoot, with the soles of the feet placed flat against the Well's box. With the hands on top of each other and knees fully pressed flat to the floor, they were asked to 
bend forward their trunk without bouncing and reach forward along the measuring line as far as possible. The best score of two attempts was recorded.

We performed the 1-minute sit-up test to measure abdominal muscle strength. Participants were positioned in the supine position with the knees flexed at 45 degrees and arms crossed over their chest. At the 'go' command, they would sit up touching the knees with their elbows, then return back to the floor and continue to perform as many sit-ups as possible in 1 minute.

We used the 9-minute run test to measure cardiorespiratory endurance. Participants were asked to run as far as possible, avoiding sprints, interspersed with walking. They were asked not to stop but they could walk if tired. The distance covered at the end of a 9-minute period was recorded.

Body fat percentage (\% fat) was assessed by measuring triceps and subscapular skinfolds with a Lange compass. We took three measures of each skinfold and calculated the median. We calculated \% fat from the Slaughter et al. equation (1988), and then classified it according to Lohman data (1987) apud Heyward and Stolarczyv. ${ }^{14}$ Socioeconomic status was classified according to the Brazilian Marketing Research Association (ABEP) criteria. $^{15}$

Statistical analyses including descriptive statistics (frequency and percentage) were performed using SPSS version 20.0. We performed the analysis of variance (one-way ANOVA) to test differences between mean scores by type of school at a significance level of $\mathrm{p}<0.05$. For Post Hoc analysis, Tukey's test was chosen.

\section{RESULTS}

Table 1 shows the characteristics of the study sample including 626 students, of which $53.2 \%$ were males, $35.1 \%$ second-graders, $51.8 \%$ lived in peripheral districts and $46.8 \%$ were socioeconomic class $\mathrm{C}$. The descriptive data showed there was a high proportion of excess weight (30.5\%) and body fat percentage exceeding the healthy range (28.0\%) and a high proportion of inadequate scores of flexibility (66.9\%), muscle strength (57.0\%) and cardiorespiratory endurance (62.8\%).

Table 2 shows the results (frequency and percentage) of physical fitness assessments by type of school. Except for muscle strength, children from public state schools where $\mathrm{PE}$ is provided by generalist teachers showed a greater proportion of inadequate results (32.8\% excess weight; $29.7 \%$ body fat percentage above the healthy range; $71.5 \%$ inadequate flexibility and $67.2 \%$ inadequate cardiorespiratory endurance). Regarding muscle strength, a greater proportion of children from public municipal schools did not achieve the healthy range (61.3\%).

Table 3 presents the mean scores (and standard deviations) as well as the $\mathrm{F}$-values and $\mathrm{p}$-values of the variables assessed. There were differences in cardiorespiratory endurance and flexibility mean scores among the types of schools. The Tukey's test showed significant differences in flexibility (state vs. municipal, $\mathrm{p}=$ 0.007 ; state vs. private, $\mathrm{p}=0.000$; municipal vs. private, $\mathrm{p}=0.046$ ). Significantly lower flexibility mean scores were found in state schools while higher mean scores were seen in private schools. As for cardiorespiratory endurance, significantly lower mean scores were found only in children from state schools (state vs. private, $\mathrm{p}$ $=0.000 ;$ state vs. municipal, $\mathrm{p}=0.008)$. 
Table 1 - Characteristics of the study sample $(n=626)$

\begin{tabular}{|c|c|c|}
\hline & & $n(\%)$ \\
\hline \multirow[t]{2}{*}{ Gender } & Female & $293(46.8)$ \\
\hline & Male & $333(53.2)$ \\
\hline \multirow[t]{3}{*}{ Type of school } & Private & $70(11.1)$ \\
\hline & Municipal & $212(33.9)$ \\
\hline & State & $344(55.0)$ \\
\hline \multirow[t]{4}{*}{ Grade } & 1 & $86(13.7)$ \\
\hline & 2 & $220(35.1)$ \\
\hline & 3 & $176(28.1)$ \\
\hline & 4 & $144(23.0)$ \\
\hline \multirow[t]{3}{*}{ School location } & Central & $169(27.0)$ \\
\hline & Peripheral area & $324(51.8)$ \\
\hline & Rural & $133(21.2)$ \\
\hline \multirow[t]{3}{*}{ Socioeconomic class } & $A-B$ & $256(40.9)$ \\
\hline & C & $291(46.5)$ \\
\hline & D-E & $79(12.6)$ \\
\hline \multirow[t]{2}{*}{ BMI } & Low/normal weight & $435(69.5)$ \\
\hline & Overweight/obesity & $191(30.5)$ \\
\hline \multirow[t]{2}{*}{ Body fat percentage } & Very low/low/optimal & $451(72.0)$ \\
\hline & Moderately high/high/very high & $175(28.0)$ \\
\hline \multirow[t]{2}{*}{ Flexibility } & Adequate & $207(33.1)$ \\
\hline & Inadequate & $419(66.9)$ \\
\hline \multirow[t]{2}{*}{ Muscle strength } & Adequate & $269(43.0)$ \\
\hline & Inadequate & $357(57.0)$ \\
\hline \multirow[t]{2}{*}{ Cardiorespiratory endurance } & Adequate & $233(37.2)$ \\
\hline & Inadequate & $393(62.8)$ \\
\hline
\end{tabular}

Table 2 - Physical fitness (frequency and percentage; $n=626$ ) by type of school (physical educator vs. generalist teacher)

\begin{tabular}{|c|c|c|c|c|}
\hline \multirow{2}{*}{$\begin{array}{l}\text { Private } \\
\mathrm{n}(\%)\end{array}$} & & \multicolumn{2}{|c|}{ Physical educator } & \multirow{2}{*}{$\begin{array}{l}\text { Generalist } \\
\text { teacher }\end{array}$} \\
\hline & & $\begin{array}{l}\text { Municipal } \\
\mathrm{n}(\%)\end{array}$ & $\begin{array}{l}\text { State } \\
\mathrm{n}(\%)\end{array}$ & \\
\hline \multirow[t]{3}{*}{$\mathrm{BMI}$} & Low/normal weight & $56(80.0)$ & $148(69.8)$ & $231(67.2)$ \\
\hline & Overweight/obesity & $14(20.0)$ & $64(30.2)$ & $113(32.8)$ \\
\hline & Total & $70(100.0)$ & $212(100.0)$ & $344(100.0)$ \\
\hline \multirow[t]{3}{*}{ Body fat percentage } & Very low/low/optimal & $54(77.1)$ & $155(73.1)$ & $242(70.3)$ \\
\hline & $\begin{array}{l}\text { Moderately high/high/ } \\
\text { very high }\end{array}$ & $16(22.9)$ & $57(26.9)$ & $102(29.7)$ \\
\hline & Total & $70(100.0)$ & $212(100.0)$ & $344(100.0)$ \\
\hline \multirow[t]{3}{*}{ Flexibility } & Adequate & $32(45.7)$ & $77(36.3)$ & $98(28.5)$ \\
\hline & Inadequate & $38(54.3)$ & $135(63.7)$ & $246(71.5)$ \\
\hline & Total & $70(100.0)$ & $212(100.0)$ & $344(100.0)$ \\
\hline \multirow[t]{3}{*}{ Muscle strength } & Adequate & $41(58.6)$ & $82(38.7)$ & $146(42.4)$ \\
\hline & Inadequate & $29(41.4)$ & $130(61.3)$ & $198(57.6)$ \\
\hline & Total & $70(100.0)$ & $212(100.0)$ & $344(100.0)$ \\
\hline \multirow{3}{*}{$\begin{array}{l}\text { Cardiorespiratory } \\
\text { endurance }\end{array}$} & Adequate & $43(61.4)$ & $77(36.3)$ & $113(32.8)$ \\
\hline & Inadequate & $27(38.6)$ & $135(63.7)$ & $231(67.2)$ \\
\hline & Total & $70(100.0)$ & $212(100.0)$ & $344(100.0)$ \\
\hline
\end{tabular}

Inadequate $=$ Very poor/poor/fair; Adequate $=$ good/very good/excellent 
Table 3 - Physical fitness (means and standard deviations, one-way ANOVA) by type of school

\begin{tabular}{|c|c|c|c|c|}
\hline & & Mean $( \pm S D)$ & $\mathrm{F}$ & $p$-value \\
\hline \multirow[t]{3}{*}{$\mathrm{BMI}$} & Private & $17.08(2.30)$ & \multirow[t]{3}{*}{1.993} & \multirow[t]{3}{*}{0.137} \\
\hline & Municipal & $17.55(3.30)$ & & \\
\hline & State & 17.88 (3.39) & & \\
\hline \multirow[t]{3}{*}{ Body fat percentage } & Private & $17.84(6.62)$ & \multirow[t]{3}{*}{0.878} & \multirow[t]{3}{*}{0.416} \\
\hline & Municipal & $19.28(9.03)$ & & \\
\hline & State & $18.95(7.36)$ & & \\
\hline \multirow[t]{3}{*}{ Flexibility } & Private & $25.79(8.10)$ & \multirow[t]{3}{*}{12.126} & \multirow[t]{3}{*}{0.000} \\
\hline & Municipal & $23.62(6.17)$ & & \\
\hline & State & $21.86(6.57)$ & & \\
\hline \multirow[t]{3}{*}{ Muscle strength } & Private & $26.21(6.81)$ & \multirow[t]{3}{*}{1.006} & \multirow[t]{3}{*}{0.366} \\
\hline & Municipal & $24.92(7.61)$ & & \\
\hline & State & $24.90(7.11)$ & & \\
\hline \multirow{3}{*}{$\begin{array}{l}\text { Cardiorespiratory } \\
\text { endurance }\end{array}$} & Private & $1268.14(217.62)$ & \multirow{3}{*}{10.593} & \multirow{3}{*}{0.000} \\
\hline & Municipal & $1213.29(186.66)$ & & \\
\hline & State & $1162.36(194.83)$ & & \\
\hline
\end{tabular}

One-factor ANOVA; means (and standard deviation); $p$-value = level of significance for $p<0.05$

\section{DISCUSSION}

The analysis of descriptive data for each variable assessed in our sample showed a higher prevalence of excess weight in children from all types of schools. This finding is consistent with that reported in a study with 356 first to fourth graders from municipal schools in the city of Pelotas, Rio Grande do Sul, of a high prevalence (43.7\%) of overweight and obesity among schoolchildren. ${ }^{16}$ Another study in the city of Itajaí, Santa Catarina, evaluated 93 first to fourth graders from a private school and found excess weight in $40.9 \%$ of the students. ${ }^{17}$ Similarly, a study with 280 students 7-10 years of age from state schools in the city of Campo Grande, Mato Grosso do Sul, found excess weight in $38.84 \%$ and $27.64 \%$ of girls and boys, respectively. ${ }^{18}$

The assessment of body fat percentage showed a high prevalence of students above the recommended range in all types of schools. This is corroborated by a study with 511 schoolchildren age 7 to 10 of high socioeconomic condition from a private school in the city of Londrina, Paraná, that found high body fat percentage in $33 \%$ of boys and $15 \%$ girls. ${ }^{19}$ However, in a study with 342 public school students age 7 to 10 in the city of Jequié, Bahia, $18 \%$ of the boys and $40 \%$ of the girls studied had body fat percentage lower than the recommended healthy level. ${ }^{20}$

Children from all types of schools showed poor flexibility scores, and most performances were inadequate. This contrasts with Werk et al. findings ${ }^{18}$ after studying schoolchildren age 7 to 10 years from a state school in the city of Campo Grande, Mato Grosso do Sul. They found the best fitness performances in the flexibility assessment, with $82.15 \%$ of girls and $91.05 \%$ of boys achieving the recommended scores. A study conducted in the city of Carneirinhos, Minas Gerais, evaluated 60 schoolchildren age 10 to 12 and found higher scores than ours. Both male and female students showed "very good" test performance. ${ }^{21}$ Another study in the city of Marechal Cândido Rondon, Paraná, evaluated 72 public schoolchildren age 7 to 10 and reported that $56.6 \%$ of the boys and $55 \%$ of the girls achieved satisfactory flexibility scores. ${ }^{22}$ 
A great proportion of children from all types of schools had poor abdominal muscle strength performance. A study with public schoolchildren age 7 to 12 in the city of Jequié, Bahia, showed that only $11 \%$ of boys and $7 \%$ of girls achieved the recommended abdominal muscle strength score..$^{20}$ The same was reported in a study in the city of Carneirinhos, Minas Gerais, that evaluated schoolchildren age 10 to 12 years: most performances were rated as "poor" and "very poor" ${ }^{21}$ On the other hand, a study with children age 7 to 10 years from state schools in the city of Campo Grande, Mato Grosso do Sul, found an adequate performance in 78.34\% of girls and $71.98 \%$ of boys. ${ }^{18}$

With respect to cardiorespiratory endurance, a higher proportion of children from state schools showed poor performance; however, inadequate scores were seen in children from all types of schools. A study with children age 7 to 12 in the city of Jequié, Bahia, found that only $15 \%$ of boys and $14 \%$ of girls achieved the recommended scores. ${ }^{20}$ Also, a study in the city of Londrina, Paraná, with 511 students age 7 to 10 of high socioeconomic condition found that only $27 \%$ of boys and $32 \%$ of girls scored within the healthy range. ${ }^{19}$

A comparison of the mean scores by type of school showed that children in the early grades from state schools (PE classes not provided by qualified physical educators) had a greater proportion of inadequate fitness performance, except for muscle strength. The mean scores for flexibility and cardiorespiratory endurance were significantly lower in children from schools where PE programs are delivered by generalist teachers.

Lower physical fitness scores in children receiving PE by generalist teachers may be attributed to lack of qualification of generalist teachers to provide PE activities. As mentioned before, although legally supported, these teachers have reported feeling insecure and unprepared to deliver PE classes and believe that qualified physical educators have a major role and are the most proficient to work with children in the early grades. ${ }^{5,6,7,8,9}$

This is consistent with the findings of Silva and $\mathrm{Krug}^{23}$ in their review of education policy and planning of undergraduate programs in $\mathrm{PE}$ and education for elementary school teachers at Universidade Federal de Santa Maria. They noted that the curriculum of the undergraduate program in education has only one $\mathrm{PE}$ course representing a 60-hour workload. In addition, Cavalaro and Muller ${ }^{24}$ reviewed the curriculum and education policy and planning of the $\mathrm{PE}$ and education programs at Universidade Estadual de Maringá and found that education students are not trained in $\mathrm{PE}$ as part of their undergraduate curriculum. Schutz ${ }^{25}$ interviewed students of a teacher training certificate program in the city of Cachoeirinha, Rio Grande do Sul, and verified that the program does not include specific PE courses and the course that most closely addresses $\mathrm{PE}$ focuses on children's games and play activities.

Key contents in PE including development of physical fitness are not an integral part of the instruction of children in the early grades. This is supported by some studies reporting that generalist teachers play a minor role in PE classes. Most activities include outdoor games and playing in a free, unstructured manner; ${ }^{5}$ most PE classes involve recreation, ball games and jump rope ${ }^{2}$ teachers prepare $\mathrm{PE}$ activities based on their own life experiences usually involving free time playing outdoors; and some teachers even regard these classes as a reward to students for good behavior. ${ }^{9}$ In a study investigating 58 generalist teachers from 12 public schools in the city of Várzea Grande, Minas Gerais, $22 \%$ of the teachers 
reported that they did not provide $\mathrm{PE}$ classes although $\mathrm{PE}$ is a compulsory curriculum subject. With respect to the contents of the classes provided by generalist teachers, $82 \%$ reported they involved free recreation and $60 \%$ games. $^{2}$

According to Soares, ${ }^{26}$ although schools have the authority to make decisions on the kind of $\mathrm{PE}$ teachers, the guidelines do not at all recommend free play instead of $\mathrm{PE}$ classes and they rather stress the importance of $\mathrm{PE}$ at school. Therefore, schools should create opportunities for involvement in adequate physical activities for children to develop their motor skills and generalist teachers should further develop their PE knowledge and skills and seek continuing education, as they are required to teach all of the subjects in the national curriculum.

A limitation of our study lies on the fact that we did not have any information available on the quality of $\mathrm{PE}$ provided to schoolchildren and neither examined the contents, proposed goals and methods used to teach PE classes nor assessed weekly frequency and duration of each class. In addition, we did not assess physical activity outside school, for instance in sports clubs, and student's physical maturation, which may have affects our results.

To the best of our knowledge there were no other similar studies comparing physical fitness of students receiving $\mathrm{PE}$ by a qualified physical educator and a generalist teacher. However, in an intervention study conducted in California including 759 fifth and sixth graders from 7 public schools, students were divided into the following subgroups: group 1 attended classes with a qualified physical educator (80 minutes per week); group 2 attended classes with a teacher trained by a PE specialist working with the research team (65 minutes per week); and group 3 attended the regular program of classes (38 minutes per week) provided by a generalist teacher. Students who attended the classes provided by a qualified physical educator achieved greater cardiovascular fitness and muscle strength. ${ }^{27}$

It is worth noting that, although a lower proportion of inadequate results were found among children from schools where $\mathrm{PE}$ is provided by a qualified physical educator compared to those from state schools, children from all types of schools studied showed a high proportion of inadequate results for all variables assessed except for muscle strength, regardless of the type of educator.

This finding shows that $\mathrm{PE}$ classes are falling short in promoting students' health and physical fitness. Although students are to some extent engaging in physical activity, they are likely not engaging at an appropriate exercise intensity and duration to enjoy physical fitness benefits. Santos ${ }^{28}$ argued that for health benefits and physical fitness these classes should involve largely moderate to vigorous activities. The effectiveness and quality of PE programs at school are closely associated with the type of activity and time devoted to physical exercises that may induce favorable physiological adaptations.

However, Guedes and Guedes, ${ }^{29}$ in a study conducted in the city of Londrina, Paraná, observed PE classes of students in the last years of elementary school and high school in 15 schools and found that only 14\% of class time-about 7 minutes of a 50-minute class-involved exercises aimed to improve physical fitness mostly including aerobic training followed by flexibility and muscle strength/ endurance exercises. In the remaining of class time students engaged in sports activities (28.3\%), unstructured games (6.7\%) and activities to develop motor skills (1\%). Much of the class time was spent managing and organizing the activities (15.5\%) and moving from an activity to the next (34.5\%). The researchers also verified through heart rate monitoring that students engaged mostly in low or very 
low intensity exercises of short duration with no resulting improvement in their physical fitness and health benefits.

Although the above mentioned study did not include children in the early years of elementary school, it revealed a concerning weakness of today's PE at school. While trying to include too many elements in a PE class, the educator is not able to work them out at the level required to bring positive health gains to students. Furthermore, educators have limited time available for $\mathrm{PE}$ activities and students remain inactive nearly $50 \%$ of class time. The structure of activities allows only few students engage in at a time while the rest just wait for their turn. ${ }^{29}$

Although physical educators are offered specific knowledge content during their undergraduate years, they find it difficult to later address this great breadth of knowledge in their classes and usually focus their activities on competitive sports such as volleyball, soccer, basketball, and handball. ${ }^{29}$

Santos $^{28}$ has claimed that for school PE programs to promote and encourage students to lead a physically active lifestyle there will be a need to overcome limitations and to focus on popularizing sports and exercise and health-related physical fitness as the main content of PE. Guedes ${ }^{30}$ has argued that it is essential that children and adolescents have access to information about how and why to engage in physical activities, and not just do something for the sake of it. Students should be educated to maintain appropriate levels of health-related physical fitness throughout life.

Physical educators have to overcome the limitations they are faced with in their teaching practices and seek to engage students in games and playful activities to enhance coordination while at the same time encouraging the promotion of health-related physical fitness at school. ${ }^{28}$

\section{CONCLUSION}

A greater proportion of excess weight and high body fat percentage and inadequate flexibility and cardiorespiratory endurance scores was found among students from state schools where PE programs are delivered by generalist teachers. There were differences in mean flexibility and cardiorespiratory endurance scores by type of school with significantly lower mean scores among state schoolchildren.

\section{REFERENCES}

1. Brasil. Lei 10.328, de 12 de dezembro de 2001. Altera o parágrafo 3o, artigo 26, da Lei 9.394, de 20 de dezembro de 1996, LDB da Educação Nacional. Presidência da República Federativa do Brasil.

2. Silva filho MF, Pereira RS. Educação Física e professores polivalentes: O caso das escolas públicas municipais de Várzea Grande. Revista Mackenzie de Educação Física e Esporte, 2012; 11(2): 161-187.

3. Brasil. Lei 9394, de 20 de dezembro de 1996. Estabelece as diretrizes e bases da educação nacional. Presidência da República Federativa do Brasil.

4. Rio Grande do Sul. Lei n. 8.747, de 21 de novembro de 1988. Dispõe sobre o Quadro de Carreira, o Quadro em Extinção e as gratificações do Magistério Estadual, dando outras providências. Sistema LEGIS. Porto Alegre, RS.

5. Pereira RS, Nista-Piccolo VL, Santos SAP. A Educação Física nas séries da fase inicial do ensino fundamental: olhar do professor polivalente. Revista da Educação Física/UEM Maringá, 2009; 20 (3):343-352. 
6. Etchepare LS, Pereira EF, Zinn JL. Educação física nas séries iniciais do Ensino Fundamental. Revista da Educação Física/UEM Maringá, 2003; 14(1): 59-66.

7. Guirra FJS. Mediação da Professora Generalista no trabalho corporal na Educação Infantil. 2007. 134f. Dissertação (Mestrado em Educação Física) - Faculdade de Educação Física, Universidade Estadual de Campinas, Campinas, 2007.

8. Contreira CB, Krug HN. Educação Física nas séries iniciais do ensino fundamental: um estudo de caso com professores unidocentes. Lecturas, Educación Física y Deportes, 2010; 15 (150).

9. 9. Darido SC. Educação Física de $1^{\mathrm{a}}$ a $4^{\mathrm{a}}$ série: quadro atual e as implicações para a formação profissional em Educação Física. Revista Paulista de Educação Física, 2001; supl 4: 61-72.

10. Betti M, Zuliani LR. Educação física escolar: uma proposta de diretrizes pedagógicas. Revista Mackenzie de Educação Física e Esporte, 2002; 1 (1): 73-81.

11. Marques AT, Gaya A. Atividade física, aptidão física e educação para a saúde: estudos na área pedagógica em Portugal e no Brasil. Revista Paulista Educação Física, 1999; 13(1):83-102.

12. Christensen LB. Experimental methodology. $2^{\circ}$ ed. Boston: Allyn/Bacon, 1980.

13. Projeto Esporte Brasil. Manual de aplicação de medidas de testes somatomotores. Porto Alegre: Universidade Federal do Rio Grande do Sul - UFRGS, 2007.

14. Heyward VH, Stolarczyk LM. Avaliação da composição corporal aplicada. São Paulo: Manole, 2000.

15. ABEP - Associação Brasileira de Empresas de Pesquisa. Critério de Classificação Econômica Brasil, 2003.

16. Flores TR, Ciochetto CR, Nunes BP, Vieira MFA. Consumo de refrigerantes entre escolares de séries iniciais da cidade de Pelotas, Rio Grande do Sul. Revista Ciência \& Saúde, 2013; 6 (1): 59-66.

17. Anzolin C, Ouriques CM, Höfelmann DA, Mezadri T. Intervenções nutricionais em escolares. Revista Brasileira em Promoção da Saúde, 2010; 23 (4): 297-306.

18. Werk R, Vieira AZ, Nuñez PRM, Habitante CA, Silva JVP. Aptidão física relacionada à saúde de crianças de uma escola estadual de Campo Grande/MS. Ciências, Cuidado e Saúde, 2009; 8(1): 42-47.

19. Ronque VER, Cyrino ES, Dorea V, et al. Diagnóstico da aptidão física em escolares de alto nível socioeconômico: avaliação referenciada por critérios de saúde. Revista Brasileira de Medicina do Esporte, 2007; 13(2):71-76.

20. Dorea V, Ronque VER, Cyrino ES, et al. Aptidão Física Relacionada à Saúde em Escolares de Jequié, BA, Brasil. Revista Brasileira de Medicina do Esporte, 2008; 1(6):494-499.

21. Verardi CEL, Lobo APS, Amaral VE, Freitas VL, Hirota VB. Análise da aptidão física relacionada à saúde e ao desempenho motor em crianças e adolescentes da cidade de Carneirinho-MG. Revista Mackenzie de Educação Física e Esporte, 2007; 6(3):127-134.

22. Strassburger M, Borges GA. Aptidão física relacionada à saúde de escolares de 7 a 10 anos de Marechal Cândido Rondon - PR. Caderno de Educação Física, 2001; 3(1):67-78.

23. Silva MS, Krug HN. A formação inicial de professores de educação física e de pedagogia: um olhar sobre a preparação para a atuação nos anos iniciais do ensino fundamental. Educación Física y Deportes, 2008; 13 (123).

24. Cavalaro AG, Muller VR. Educação Física na Educação Infantil: uma realidade almejada. Educar, 2009; (34): 241-250.

25. Schütz MB. A formação de normalistas para o trato da educação física nas séries iniciais do ensino fundamental: um estudo de caso na rede estadual do RS. 2011.71f. Trabalho de Conclusão de Curso (Curso de Educação Física: Licenciatura) - Escola de Educação Física, Universidade Federal do Rio Grande do Sul, Porto Alegre, 2011.

26. Soares ES. Importância do profissional de Educação Física nos anos iniciais do ensino fundamental. 2012. 47f. Trabalho de Conclusão de Curso (Curso de Educação Física: Bacharelado) - Universidade Regional do Noroeste do Estado do Rio Grande do Sul (Unijuí), Ijuí, 2012.

27. Sallis JF, Mckenzie TL, Kolody B, et al. Effects of Health-Related Physical Education on Academic Achievement: SPARK. Research Quarterly for Exercise and Sport, 1999; 70:127-134. 
28. Santos DF. Perfil dos Programas de Educação Física Escolar. 2012. 45f. Trabalho de Conclusão de Curso (Curso de Educação Física) - Escola de Educação Física, Universidade Federal do Rio Grande do Sul, Porto Alegre, 2012.

29. Guedes JERP, Guedes DP. Características dos programas de educação física escolar. Revista Paulista de Educação Física, 1997; 11(1): 49-62.

30. Guedes DP. Educação para a saúde mediante programas de Educação Física Escolar. Motriz, $1999 ; 5(1)$.

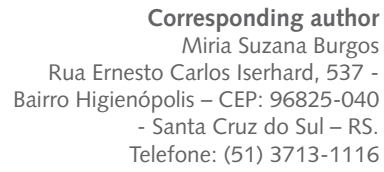

Received 09/03/2012

Revised 12/07/2012

$06 / 03 / 2013$

Approved 08/16/2013 